Article

\title{
Sodium Rechargeable Batteries with Electrolytes Based on Nafion Membranes Intercalated by Mixtures of Organic Solvents
}

\author{
Tatiana Kulova $^{1, *}$, Alexander Skundin ${ }^{1}\left(\mathbb{D}\right.$, Andrey Chekannikov ${ }^{2}$, Svetlana Novikova ${ }^{3}$, \\ Daria Voropaeva ${ }^{4}$ and Andrey Yaroslavtsev ${ }^{3}$ \\ 1 A.N. Frumkin Institute of Physical Chemistry and Electrochemistry of the Russian Academy of Sciences, \\ 31-4, Leninskii Prospect, Moscow 119071, Russia; askundin@mail.ru \\ 2 Skolkovsky Institute of Science and Technology, 3, ul. Nobel, Moscow 121205, Russia; \\ andrey.chekannikov@gmail.com \\ 3 N.S. Kurnakov Institute of General and Inorganic Chemistry of the Russian Academy of Sciences, \\ 31, Leninskii Prospect, Moscow 119991, Russia; svetlana_novi@mail.ru (S.N.); yaroslav@igic.ras.ru (A.Y.) \\ 4 Lomonosov Moscow State University, 1 Leninskie gory, Moscow 119991, Russia; voropaeva-dd@yandex.ru \\ * Correspondence tkulova@mail.ru; Tel.: +7-910-444-92-87
}

Received: 17 October 2018; Accepted: 31 October 2018; Published: 1 December 2018

check for updates

\begin{abstract}
The possibilities of manufacturing batteries with Nafion 117 membranes in the $\mathrm{Na}^{+}$-form intercalated by mixtures of non-aqueous organic solvents used both as an electrolyte, separator, and binder were investigated. Electrochemical stability of various organic solvent mixtures based on $N, N$-dimethylacetamide, ethylene carbonate, propylene carbonate, and tetrahydrofuran were characterized. It was shown that a sodium battery based on a Nafion-Na membrane intercalated by mixture of ethylene carbonate and propylene carbonate with a $\mathrm{Na}_{3} \mathrm{~V}_{1.9} \mathrm{Fe}_{0.1}\left(\mathrm{PO}_{4}\right)_{3} / \mathrm{C}$ positive electrode is characterized by a discharge capacity of $\approx 110 \mathrm{mAh} \cdot \mathrm{g}^{-1}$ (current density of $10 \mathrm{~mA} \cdot \mathrm{g}^{-1}$ ) at room temperature and shows the ability to cycle without degradation during 20 cycles. Batteries with Nafion membrane electrolytes, containing $N, N$-dimethylacetamide, were characterized using capacity fading during cycling, which is due to the interaction of $N, N$-dimethylacetamide and a negative sodium electrode.
\end{abstract}

Keywords: sodium rechargeable battery; polymer electrolyte; Nafion; cycle stability; electrochemical stability

\section{Introduction}

Of late, sodium-ion batteries have attracted keen attention [1-3]. In such batteries, the positive and negative electrodes are made of materials capable of reversibly inserting sodium without the release of a free metallic phase. This is what ensures their safe functioning. Sodium rechargeable batteries differ from sodium-ion counterparts in that sodium metal is used as a negative electrode in such batteries. The theoretical specific capacity of metallic sodium during its anodic dissolution amounts to $1165 \mathrm{mAh} \cdot \mathrm{g}^{-1}$, which is much higher than that of intercalation compounds of the negative electrode of the sodium-ion batteries. For example, sodium titanate $\left(\mathrm{Na}_{4} \mathrm{Ti}_{3} \mathrm{O}_{7}\right)$, sodiated hard carbon $\left(\mathrm{Na}_{6} \mathrm{C}\right)$, sodiated germanium $\left(\mathrm{Na}_{1.6} \mathrm{Ge}\right)$, and sodiated phosphorus $\left(\mathrm{Na}_{3} \mathrm{P}\right)$ have a theoretical specific capacity for sodium extraction of 154, 282, 390, and $804 \mathrm{mAh} \cdot \mathrm{g}^{-1}$, respectively [4]. In addition, the potential of sodium metal at its anodic dissolution is noticeably more negative than that of intercalation electrodes during discharge, which contributes to an increase in the discharge voltage of the battery. At the same time, it is known that metallic sodium (as well as metallic lithium) is not capable of prolonged cycling 
in liquid electrolytes due to encapsulation and dendrite formation. The latter can lead to a shorting and ignition of the battery with metallic sodium.

The use of a solid polymer electrolyte, in principle, can create a battery with a metallic sodium negative electrode, the energy density of which will be higher than that of the sodium-ion battery. Another advantage of using a solid polymer electrolyte consists in its flexibility, which makes it possible to obtain a large area of electrolyte, and to design batteries of different geometries. In addition, the use of polymer electrolytes reduces the known effect of the volume changes of electrode material during sodium intercalation/deintercalation [5,6].

To date, quite a lot of work has been published on the creation and investigation of sodium-ion solid polymer electrolytes [7-10]. The most widespread class of polymer electrolytes are true solid polymer electrolytes [7]. They are based on polymer matrices in which sodium salts with a bulky anion are dissolved. In most cases, the polymer basis of such electrolytes is polyethylene oxide [11]. Such electrolytes are characterized by low ionic conductivity at room temperature $\left(\approx 10^{-5} \mathrm{~S} \cdot \mathrm{cm}^{-1}\right)$ [12]. Replacement of salts with membrane ionogenic groups, such as $-\mathrm{SO}^{3-},-\mathrm{COO}^{-}$, etc., as well as the addition of a low-molecular plasticizer, allows higher conductivity values $[9,13]$. The most promising polymer electrolytes at present are Nafion-type membranes. Due to the perfluorinated polymer matrix, they have high thermal and electrochemical stability, as well as a high degree of dissociation of functional groups, which ensures high ionic conductivity [14-16].

Initially electrolytes based on the Nafion membrane were proposed for lithium-ion batteries [17-24], and later for their sodium-ionic analogs $[8,25,26]$. Such electrolytes are obtained by transferring Nafion from a hydrogen to a sodium form (ion exchange in aqueous solutions of sodium salts), followed by removal of water and impregnation with an aprotic solvent. Thus, in fact, they are gel-polymer electrolytes. The principal possibility of creating a sodium battery is mentioned in Reference [25] using the example of the Nafion membrane in sodium form intercalated by a mixture of ethylene carbonate (EC) and propylene carbonate (PC). In that work, $\mathrm{Na}_{0.44} \mathrm{MnO}_{2}$ was used as the active material of the positive electrode. The conductivity of the resulting electrolyte was $0.35 \mathrm{mS} \cdot \mathrm{cm}^{-1}$ at room temperature and $1.52 \mathrm{mS} \cdot \mathrm{cm}^{-1}$ at $70{ }^{\circ} \mathrm{C}$. The laboratory cell was tested at a temperature of $45^{\circ} \mathrm{C}$ and demonstrated smaller values of the discharge capacity, but better cyclability than that with a liquid electrolyte ( $1 \mathrm{M} \mathrm{NaClO}_{4}$ in an EC-PC mixture).

Recently, the influence of the nature of organic solvents impregnating the membrane in the sodium form on the ionic conductivity was investigated [26]. A certain correlation (but not proportionality) was found between the solvent uptake and the ionic conductivity. Membranes, impregnated with solvents containing N, N dimethylacetamide (DMA), namely EC-DMA, EC-diethyl carbonate (DEC)-DMA, and PC-DMA-tetrahydrofuran (THF), are characterized by the highest ionic conductivity $\left(\approx 4 \mathrm{mS} \cdot \mathrm{cm}^{-1}\right.$ at $30^{\circ} \mathrm{C}$ ).

The purpose of this work was to investigate the possibilities of manufacturing batteries with similar polymer electrolytes based on Nafion membranes in the $\mathrm{Na}^{+}$-form. It was taken into account that not only their ionic conductivity, but also their electrochemical stability and interaction with electrode materials are important features of polymer electrolytes.

\section{Results}

\subsection{The Composition of the Materials Obtained}

The IR spectra of the obtained electrolytes (Figure S1 of the Supplementary Materials) are identical to the spectra presented in the Supplementary of the paper [26]. The presence of organic solvents in membranes was revealed by a set of vibrational frequencies inherent in these solvent molecules. In the frequency range $1600-1800 \mathrm{~cm}^{-1}$, the $\mathrm{C}=\mathrm{O}$ stretching vibrations characteristic of organic carbonates (EC, PC and DEC) were observed; at a frequency of $\approx 1640 \mathrm{~cm}^{-1}$, a band corresponding to the valence vibration of the $\mathrm{C}=\mathrm{O}$ bond in the DMA molecule could be singled out; the presence of the THF molecule could be detected by the characteristic antisymmetric valence vibration of the ring 
characteristic of cyclic ethers at $\approx 906 \mathrm{~cm}^{-1}$. The absence of vibrations of $\mathrm{OH}$ groups at $\approx 3490 \mathrm{~cm}^{-1}$ in the IR spectra of the obtained samples indicated that the membranes containing aprotic solvents and their mixtures contained no water or methanol. According to the X-ray diffraction data (Figure S2 of the Supplementary Materials), $\mathrm{Na}_{3} \mathrm{~V}_{1.9} \mathrm{Fe}_{0.1}\left(\mathrm{PO}_{4}\right)_{3} / \mathrm{C}$ is a rhombohedral modification of the NASICON structure ( $\mathrm{R} \overline{3} \mathrm{c}$ space group). The carbon of the composite is $\mathrm{X}$-ray amorphous. According to elemental analysis, the carbon content in $\mathrm{Na}_{3} \mathrm{~V}_{1.9} \mathrm{Fe}_{0.1}\left(\mathrm{PO}_{4}\right)_{3} / \mathrm{C}$ was $8.9 \%$ by weight. According to EDX data this composite contains $\mathrm{Na}, \mathrm{V}, \mathrm{P}, \mathrm{O}, \mathrm{C}$ and Fe. The ratio of the elements $\mathrm{Na}: \mathrm{V}: \mathrm{P}: \mathrm{Fe}$ corresponded to the initial load.

\subsection{The Electrochemical Stability of Polymer Electrolyte Liquid Phase}

Figure 1 shows cyclic voltammograms (CVs) for liquid electrolytes based on different solvent mixtures in the potential range from 0.001 to $4.5 \mathrm{~V}$ versus $\mathrm{Na} / \mathrm{Na}^{+}$at a potential scan rate of $10 \mathrm{mV} \cdot \mathrm{s}^{-1}$. For all electrolytes, the first two cycles of $\mathrm{CV}$ are shown. Attention must be drawn to the difference in scale of the ordinates in Figure 1a,b.

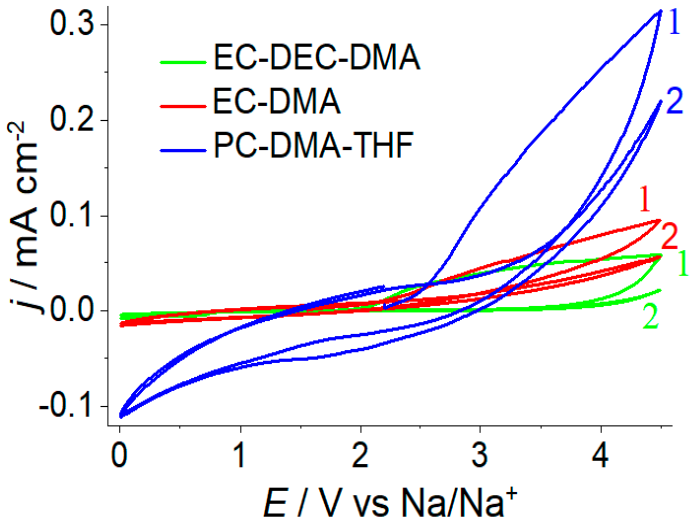

(a)

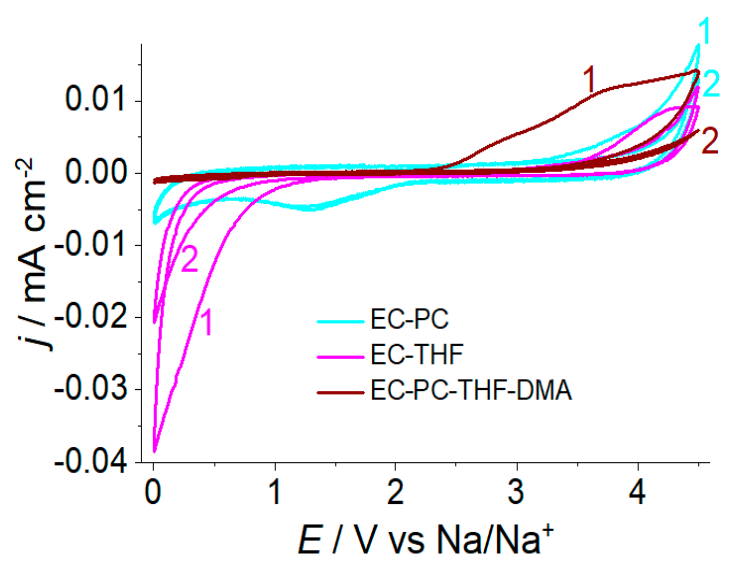

(b)

Figure 1. $\mathrm{CVs}$ at aluminum electrode in $1 \mathrm{M} \mathrm{NaClO}_{4}$ in mixtures of solvents: (a) EC-DEC-DMA, EC-DMA, PC-DMA-THF and (b) EC-PC, EC-THF, EC-PC-THF-DMA at scan rate $10 \mathrm{mV} \mathrm{s}{ }^{-1}$. Solvents compositions and cycle numbers are shown at the figures.

The lowest electrochemical stability was noted for $1 \mathrm{M} \mathrm{NaClO}_{4}$ in a three-component mixture of PC-DMA-THF (Figure 1a). In this case, the anode process proceeds at potentials somewhat more positive than $2 \mathrm{~V}$. The nature of the anode process remains uncertain. Undoubtedly, a certain part of the current is spent for anodic dissolution of aluminum with the possible formation of any complex compounds, since after the registration of the CVs on the aluminum electrode, certain signs of local corrosion that were distributed unevenly over the electrode surface were noticeable. At the same time, an appreciable part of the anode charge was spent on oxidizing the components of the electrolyte, most likely DMA. Similar, but less intense, anode processes at potentials more positive than $2 \mathrm{~V}$ were observed for all DMA-containing solvents (Figure $1 \mathrm{a}, \mathrm{b}$ ). The cathode process, which took place in a $1 \mathrm{M}$ solution of $\mathrm{NaClO}_{4}$ in a three-component mixture of PC-DMA-THF at potentials more negative than $3 \mathrm{~V}$, refers to the reduction of oxidation products of DMA in the previous anode semi-cycle, since at the CVs taken in such a solution in the potential range from 0 to $2 \mathrm{~V}$, cathode currents of less than $0.002 \mathrm{~mA} \cdot \mathrm{cm}^{-2}$ were recorded, i.e., it was almost three orders of magnitude smaller than that shown in Figure 1a.

The highest electrochemical stability from all the electrolytes studied refers to $1 \mathrm{M} \mathrm{NaClO}_{4}$ in a four-component EC-PC-THF-DMA solvent, as well as to solutions in a binary EC-PC and EC-THF mixtures (Figure 1b). 
The anode processes described above (Figure 1a) are conjugated to a certain passivation of the aluminum electrode. It is possible to trace the passivation of the aluminum electrode in various electrolytes by analyzing Figure 2, which shows CVs for the first six cycles with an increasing range of cycling potentials. As can be seen from Figure $2 \mathrm{a}, 1 \mathrm{M} \mathrm{NaClO}_{4}$ in the EC-DMA mixture was susceptible to oxidation at potentials more positive than $2 \mathrm{~V}$ and caused passivation of the aluminum electrode during cycling. A noticeable electrolyte oxidation at potentials more positive than $2 \mathrm{~V}$ was also noted for $1 \mathrm{M} \mathrm{NaClO}_{4}$ in mixtures of EC-DEC-DMA (Figure $2 \mathrm{~b}$ ). In the solution of $\mathrm{NaClO}_{4}$ in the four-component EC-PC-DMA-THF mixture, the rate of anodic oxidation was much lower than in previous electrolytes (Figure 2c), and a gradual passivation of the electrode was also observed here. The smallest passivation of the aluminum electrode was noted for a $1 \mathrm{M} \mathrm{NaClO}_{4}$ in a mixture of PC-DMA-THF (Figure 2d). When the aluminum electrode was cycled in $\mathrm{NaClO}_{4}$ solutions in mixtures of EC-DMA, EC-DEC-DMA, and EC-PC-DMA-THF (i.e., in all solutions containing EC), passivation led to gradual inhibition of the anodic process. This did not occur in a solution of $\mathrm{NaClO}_{4}$ in the PC-DMA-THF mixture (Figure 2d), therefore, when using such a solution, a permanent irreversible capacity loss appeared in the battery, which excludes the use of such a solvent in practical devices.

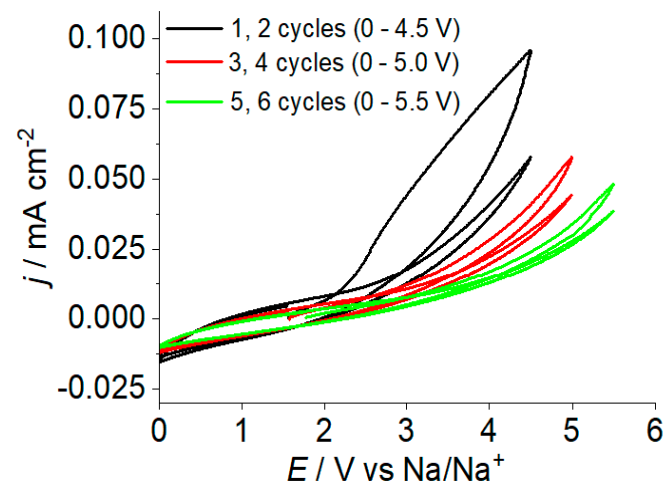

(a)

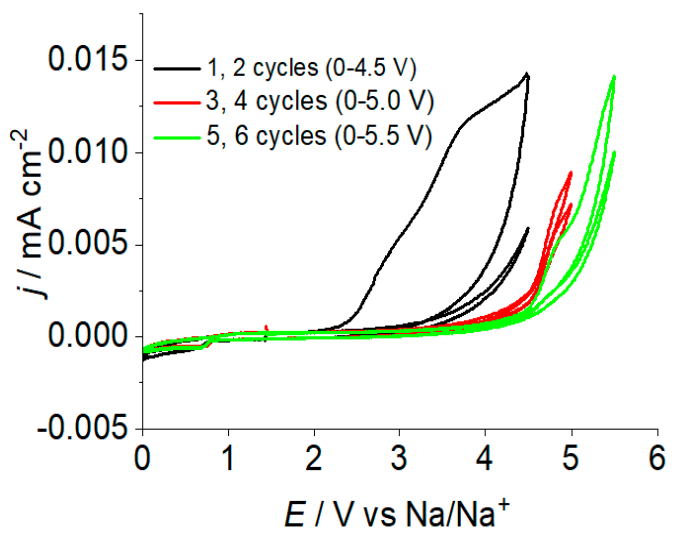

(c)

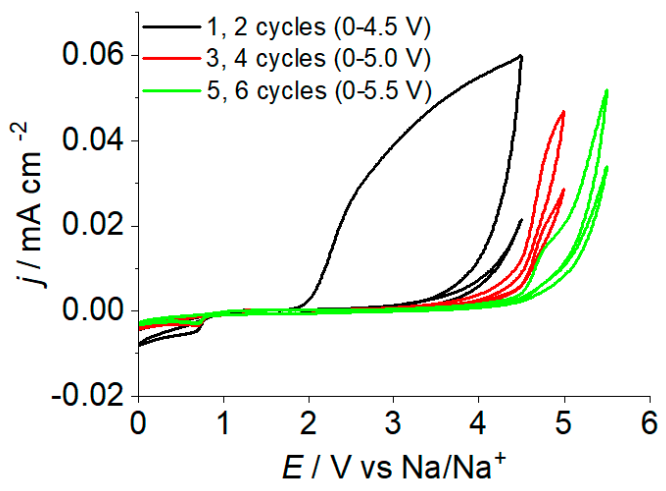

(b)

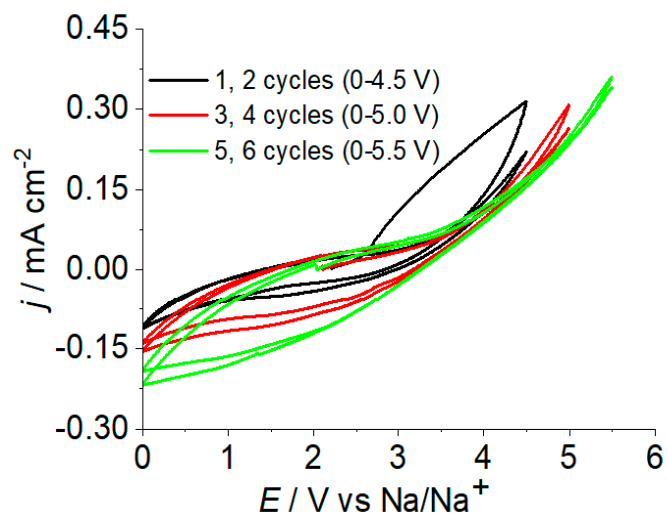

(d)

Figure 2. Aluminum electrode passivation at cyclic polarization in different electrolytes: (a) $1 \mathrm{M} \mathrm{NaClO}_{4}$ in EC-DMA, (b) $1 \mathrm{M} \mathrm{NaClO}_{4}$ in EC-DEC-DMA, (c) $1 \mathrm{M} \mathrm{NaClO}_{4}$ in EC-PC-DMA-THF, and (d) $1 \mathrm{M}$ $\mathrm{NaClO}_{4}$ in PC-DMA-THF.

The oxidation rate of DMA depends significantly on which mixture it was in (Figures 1 and 2). The oxidation rate (currents at potentials more positive than $2 \mathrm{~V}$ ) decreased in the series PC-DMA-THF $>$ EC-DMA > EC-DEC-DMA > EC-PC-THF-DMA. This thesis was also confirmed by the results of a cyclic voltammetric study of a $1 \mathrm{M}$ solution of $\mathrm{NaClO}_{4}$ in plain DMA. The corresponding CVs are shown in Figure 3. 


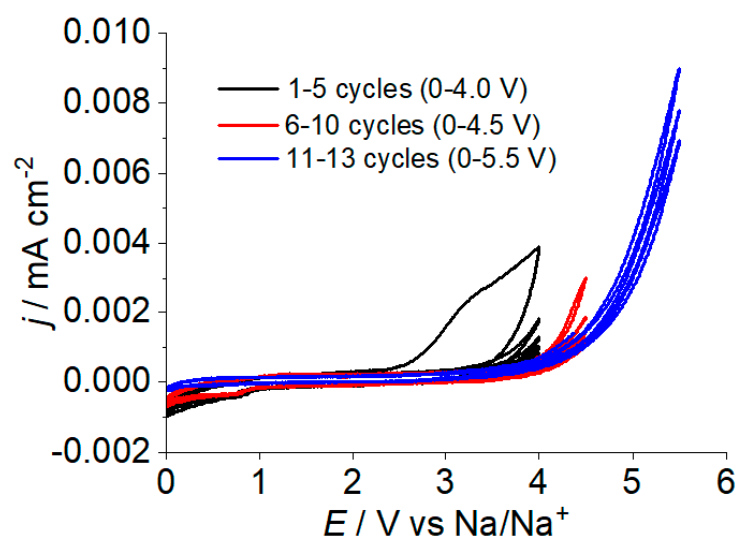

Figure 3. $\mathrm{CVs}$ in $1 \mathrm{M} \mathrm{NaClO}_{4}$ in $\mathrm{DMA}$ at enlarging potential range. Cycle numbers are shown.

The rate of the anodic process in a solution of $\mathrm{NaClO}_{4}$ in plain DMA was seen to be noticeably lower than in a $1 \mathrm{M} \mathrm{NaClO}_{4}$ in a three-component mixture PC-DMA-THF. It can be assumed that in this case it was precisely THF that had a de-passivating effect on the aluminum surface.

When cyclic voltammetric measurements were carried out, one feature of a $1 \mathrm{M}$ solution of sodium perchlorate in a mixture of PC-DMA-THF solvents was disclosed. When this solution was brought into contact with the sodium electrode, the solution became red-brown, and the staining intensity increased with time. With enough contact time, the solution viscosity increased up to solidification. It was found by separate experiments that the active component of the solvent in this case was DMA. According to References [27-29], we can suppose that some complex between DMA and $\mathrm{Na}^{+}$-ion was formed. Interestingly, when other solutions containing DMA (solutions of $\mathrm{NaClO}_{4}$ in mixtures EC-DMA, EC-DEC-DMA, and EC-PC-DMA-THF) come into contact with sodium, the color change of the solution was much slower. This phenomenon is most likely explained by the fact that all these solutions contained EC, and when sodium was in contact with such solutions, a fairly strong passive film (solid electrolyte interphase-SEI) formed on its surface, which significantly inhibited the interaction of sodium with the solution. A separate publication will be devoted to the mechanism of chemical interaction of sodium with DMA with a detailed analysis of the products formed.

\subsection{The Rechargeable Battery with a Polymer Electrolyte}

As was already mentioned above, the ionic conductivity of the polymer electrolyte was an important but not the determining parameter in deciding the applicability of the electrolyte in sodium batteries. Also, it was essential to operate the positive electrode in contact with a certain polymer electrolyte. Finally, this issue could be solved only by testing the real batteries. In this work, coin cells with polymer membranes intercalated by solvents EC-PC and EC-PC-THF-DMA were tested. In the case of using a polymer membrane intercalated by an EC-PC mixture, it was of interest to compare our results with the results given in Reference [25], where the electrolyte was also a Nafion membrane in sodium form intercalated by an EC-PC mixture, and $\mathrm{Na}_{0.44} \mathrm{MnO}_{2}$ was used in a positive electrode. It was found via separate experiments that the membrane intercalated by the four-component mixture of EC-PC-THF-DMA had almost an order of magnitude higher electrical conductivity (more than $4 \mathrm{mS} \cdot \mathrm{cm}^{-1}$ at $30^{\circ} \mathrm{C}$ ) compared to the membrane intercalated by EC-PC $\left(\approx 0.7 \mathrm{mS} \cdot \mathrm{cm}^{-1}\right.$ at $\left.30^{\circ} \mathrm{C}\right)$ [26], with close electrochemical stability (Table 1$)$.

Table 1. Physical properties of membrane electrolytes.

\begin{tabular}{cccc}
\hline Electrolyte & Thickness, $\boldsymbol{\mu m}$ & $\begin{array}{c}\text { Solvent Uptake } \\
\left(\mathbf{n}\left(\text { Solvent/n( }\left(\mathbf{S O}_{\mathbf{3}}-\right)\right)\right.\end{array}$ & $\begin{array}{c}\text { Conductivity at } \\
\mathbf{3 0}^{\circ} \mathbf{C}, \mathbf{~} \mathbf{~ S} \cdot \mathbf{c m}^{-\mathbf{1}}\end{array}$ \\
\hline Nafion 117-EC-PC & 240 & 19.8 & 0.7 \\
Nafion 117-EC-PC-THF-DMA & 260 & 24.3 & 4.1 \\
\hline
\end{tabular}


Besides, the selected membranes were characterized by a minimum decrease in conductivity with decreasing temperature.

Figure 4 shows the charge-discharge curves for coin cells with polymer electrolytes based on a Nafion 117 membrane intercalated by EC-PC (Figure 4a) and EC-PC-DMA-THF (Figure 4b) mixtures.

The current density was $10 \mathrm{~mA} \cdot \mathrm{g}^{-1}$ of active cathode material $\left(\mathrm{Na}_{3} \mathrm{~V}_{1.9} \mathrm{Fe}_{0.1}\left(\mathrm{PO}_{4}\right)_{3} / \mathrm{C}\right)$. For comparison, the similar coin cell with a liquid electrolyte $\left(1 \mathrm{M} \mathrm{NaClO}_{4}\right.$ in a mixture of EC-PC) was also tested. The positive electrode in such a cell was made of $\mathrm{Na}_{3} \mathrm{~V}_{1.9} \mathrm{Fe}_{0.1}\left(\mathrm{PO}_{4}\right)_{3} / \mathrm{C}$ with a polyvinylidene difluoride binder.

The charge-discharge curves of coin cells with polymer electrolyte were generally similar to the charge-discharge curves of a battery with a liquid electrolyte, namely, the charge proceeded at a voltage of about $3.5 \mathrm{~V}$ and discharged at a voltage of about $3.3 \mathrm{~V}$.

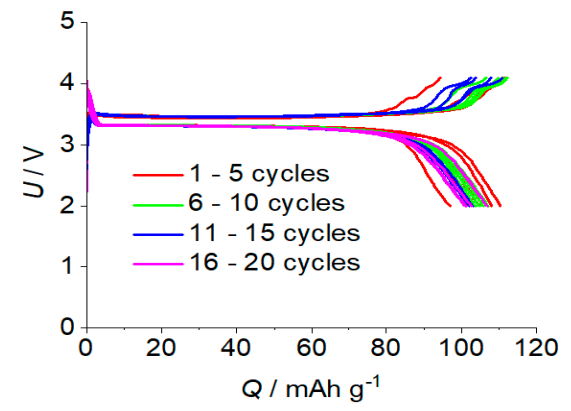

(a)

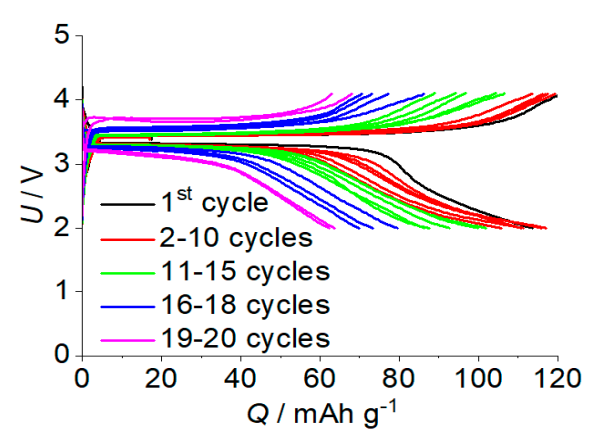

(b)

Figure 4. Charge-discharge curves of coin cells with polymer electrolytes based on Nafion 117, intercalated by EC-PC (a) and EC-PC-DMA-THF (b) mixtures. Current density of $10 \mathrm{~mA} \cdot \mathrm{g}^{-1}$.

A slight difference appeared in the shape of a charging curve on which for a cell with a polymer electrolyte intercalated by the EC-PC mixture, the second plateau was recorded at a voltage higher than $3.9 \mathrm{~V}$. The nature of this plateau was not clear, but we can suppose that its appearance may be due to the difficulty of extracting the last portions of sodium from $\mathrm{Na}_{3} \mathrm{~V}_{1.9} \mathrm{Fe}_{0.1}\left(\mathrm{PO}_{4}\right)_{3} / \mathrm{C}$ in contact with the polymer electrolyte and consequently an increase in concentration polarization.

Comparison of the charge-discharge curves of three cells (Figure 5) shows that when cycling in such a low rate $\left(10 \mathrm{~mA} \cdot \mathrm{g}^{-1}\right)$, the difference in the voltage of the cells did not exceed the experimental discrepancy. This was not surprising. The ohmic voltage drop in the polymer electrolyte with thickness is $0.4 \mathrm{~mm}$, at a current density of $10 \mathrm{~mA} \cdot \mathrm{g}^{-1}$ was estimated as $8 \mathrm{mV}$ for a cell with a polymer electrolyte based on an EC-PC mixture and about $1 \mathrm{mV}$ for a cell with a polymer electrolyte intercalated by a four-component solution.

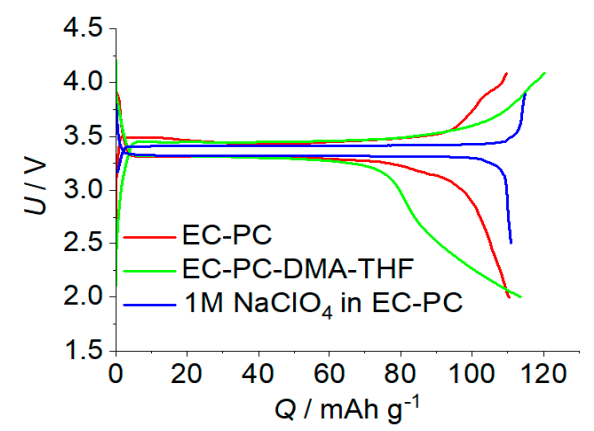

(a)

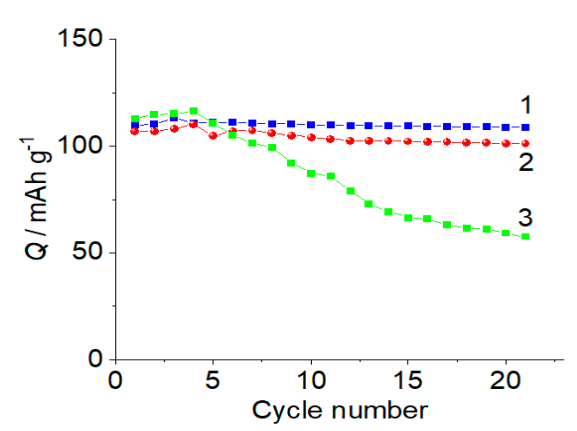

(b)

Figure 5. Charge-discharge curves (a) and cycling stability (b) for coin cells with liquid (1) and polymer electrolytes (2,3). (1) - $1 \mathrm{M} \mathrm{NaClO}_{4}$ in EC-PC, (2)—Nafion 117 membrane, intercalated by EC-PC mixture, (3)-Nafion 117 membrane, intercalated by a EC-PC-DMA-THF mixture.The capacity was normalized by a weight of cathode active material current density of $10 \mathrm{~mA} \cdot \mathrm{g}^{-1}$. 


\section{Discussions}

It is worth noting that a battery with a polymer electrolyte based on a Nafion 117 membrane intercalated by an EC-PC mixture is fully functional. From the battery described in Reference [25], it is advantageously distinguished by the practical constancy of the discharge voltage, which is explained by the features of the positive electrode from sodium vanadium-iron-phosphate. Besides, in the battery in the present work, a polymer electrolyte was used as a binder of the positive electrode, which ensured a more complete utilization of the entire volume of the active material. The initial capacity of a battery with a polymer electrolyte based on a Nafion 117 membrane intercalated by an EC-PC mixture was slightly lower than the corresponding value for a liquid electrolyte battery. However, with further cycling, almost identical values of the discharge capacity were recorded. The specific capacity of the electrode from the composite of sodium vanadium-iron-phosphate with carbon, registered in this work when cycling a battery with polymer electrolyte on the basis of a mixture of EC-PC at room temperature at current density of $10 \mathrm{~mA} \cdot \mathrm{g}^{-1}$ was about $100 \mathrm{mAh} \cdot \mathrm{g}^{-1}$. Taking into account the content of carbon (8.9 $\mathrm{wt} \%$ ) in the $\mathrm{Na}_{3} \mathrm{~V}_{1.9} \mathrm{Fe}_{0.1}\left(\mathrm{PO}_{4}\right)_{3} / \mathrm{C}$ composite, the discharge capacity was close to the theoretical value. Figure $5 \mathrm{a}, \mathrm{b}$ shows the data on coin cells with liquid and polymer electrolytes cycling.

The discharge capacity of a coin cell with a polymer electrolyte based on the Nafion117 membrane intercalated by the EC-PC-DMA-THF mixture at the initial cycles was slightly higher than that of the cells with a liquid electrolyte and EC-PC-based polymer electrolyte. However, with a further cycling for the coin cell with the Nafion 117 membrane intercalated by the EC-PC-DMA-THF mixture, a noticeable capacity fading was recorded, which was due to the chemical interaction of DMA and metallic sodium. The stable operation of a battery with a polymer electrolyte based on the Nafion 117 membrane intercalated by a EC-PC mixture for 20 cycles demonstrated the principal possibility of manufacturing a sodium battery with such a polymer electrolyte and a positive electrode based on $\mathrm{Na}_{3} \mathrm{~V}_{1.9} \mathrm{Fe}_{0.1}\left(\mathrm{PO}_{4}\right)_{3} / \mathrm{C}$, capable of cycling without passivation and excessive degradation. It is worth noting that one of the important challenges in the design of a solid electrolyte battery is to ensure a good contact at the electrode/electrolyte interface. In the case of inorganic solid electrolytes, this is achieved by making composite electrodes (active material/electrolyte/carbon) followed by high-temperature sintering [30-32]. However, this does not completely solve the problem in the case of a thick layer of electrode material and with multiple intercalation/deintercalation, which is accompanied by a change in volume. The use of a polymeric binder and polymer electrolyte promotes good cycling by reducing the effect of changes in the volume of electrode material during intercalation/deintercalation. However, in the case of a non-conductive binder, the capacity of such cells is inferior to that of similar cells with liquid electrolyte. Thus, the initial capacity of the electrode based on $\mathrm{Na}_{0.44} \mathrm{MnO}_{2}$ at $45{ }^{\circ} \mathrm{C}$ in the $\mathrm{C} / 20$ mode was inferior to the values obtained with the use of a liquid electrolyte and did not exceed $60 \mathrm{mAh} \cdot \mathrm{g}^{-1}$. In this work, the perfluorinated membrane in the $\mathrm{Na}^{+}$form was used both as an electrolyte and as a binder. As a result, the capacity of the battery with polymer electrolyte based on the EC-PC mixture is comparable with the corresponding value for a battery with liquid electrolyte. The obtained result indicates a good contact of the polymer electrolyte and particles of the electrode material over the entire thickness of the electrode.

The theoretical energy density (based on the weight of active materials only) of sodium battery with a polymer electrolyte and a positive electrode based on the $\mathrm{Na}_{3} \mathrm{~V}_{1.9} \mathrm{Fe}_{0.1}\left(\mathrm{PO}_{4}\right)_{3} / \mathrm{C}$ composite amounts to $360 \mathrm{Wh} \cdot \mathrm{kg}^{-1}$. With due account for the weight of structural materials and polymer electrolyte of smaller thickness (less than $0.1 \mathrm{~mm}$ ), one can expect to achieve a practical energy density of 180-200 Wh. $\mathrm{kg}^{-1}$, which seems quite optimistic. The use of positive electrodes in a sodium battery with an active material having a higher specific capacity than $\mathrm{Na}_{3} \mathrm{~V}_{1.9} \mathrm{Fe}_{0.1}\left(\mathrm{PO}_{4}\right)_{3}$ will result in a corresponding increase in the energy density. 


\section{Materials and Methods}

\subsection{Preparation of Electrolytes Based on a Nafion Membrane}

The membranes were made by the same procedure as described in Reference [26]. The commercial Nafion 117 membrane manufactured by DuPont Co. (Wilmington, DE, USA) was conditioned according to scheme [33], then it was kept for two days in a $2 \mathrm{M}$ aqueous $\mathrm{NaCl}$ solution with constant stirring. The membrane was then washed several times with deionized water until the chloride ions were completely removed and dried under vacuum at a temperature of $70{ }^{\circ} \mathrm{C}$ for $12 \mathrm{~h}$. After that, the membrane was aged for $6 \mathrm{~h}$ in methanol at a temperature of $60^{\circ} \mathrm{C}$ and again dried under vacuum. Such treatment with methanol contributed to an appreciable expansion of the pores in the membrane. The final operation was the soaking of membranes in mixed solvents. This operation was carried out in a glove box with an argon atmosphere containing less than 1 ppm of oxygen and water vapor. In the present study, the following mixtures of aprotic solvents containing equal volumes of components have been studied: EC-DMA, EC-PC, EC-THF, EC-DEC-DMA, PC-DMA-THF, and EC-PC-THF-DMA.

\subsection{The Binder Preparation}

A membrane-based binder was prepared by the following procedure: a membrane was casted from a $5 \mathrm{wt} \%$ solution of a Nafion in a proton form in a mixture of lower aliphatic alcohols and water (55:45). Then this membrane was transferred to the $\mathrm{Na}^{+}$form by ion exchange in a manner like the one described above. The resulting Nafion-Na membrane was dried in vacuum at $70^{\circ} \mathrm{C}$. The dry polymer was placed in the calculated amount of dimethylformamide (DMFA) to prepare a $10 \mathrm{wt} \%$ solution. Dissolution took place at room temperature for 1 day with constant stirring.

\subsection{The Cathode Material Synthesis}

The $\mathrm{Na}_{3} \mathrm{~V}_{1.9} \mathrm{Fe}_{0.1}\left(\mathrm{PO}_{4}\right)_{3} / \mathrm{C}$ nanocomposite was synthesized by the modified Pechini method according to the procedure described in References [34,35] using $\mathrm{V}_{2} \mathrm{O}_{5}, \mathrm{Fe}\left(\mathrm{NO}_{3}\right)_{3} \cdot 9 \mathrm{H}_{2} \mathrm{O}, \mathrm{NaNO}_{3}$, $\mathrm{NH}_{4} \mathrm{H}_{2} \mathrm{PO}_{4}$, oxalic acid (a chelating agent and a reducer), ethylene glycol, and citric acid. The polycondensation of ethylene glycol and citric acid led to the formation of a polymer matrix that inhibited the growth of the composite particles.

\subsection{The Materials Characterization}

The infrared (IR) spectra of the obtained electrolytes based on Nafion membranes were recorded with a Nicolet iS5 IR spectrometer with a SpecacQuest attachment (Thermo Fisher Scientific, Waltham, MA, USA) in the attenuated total reflection mode with a diamond crystal in the wavenumber range of 500-4000 $\mathrm{cm}^{-1}$. The phase composition of the synthesized cathode material was characterized using a Rigaku D/MAX diffractometer (Rigaku Corp., Tokyo, Japan), $\mathrm{CuK}_{\alpha}$ radiation in the range of $10-60^{\circ} 2 \theta$. The carbon content of the composite was determined using a CHNS analyzer EuroEA 3000 (Evro Vector S.r.l., Pavia, Italy). The chemical composition of the cathode material was determined using a scanning electron microscope Carl Zeiss NVision 40 (Zeiss AG, Oberkochon, Germany) equipped with an energy dispersive X-ray (EDX) analyzer Oxford X-Max. Ionic conductivity was measured by impedance spectroscopy using an Elins Z-1500J AC bridge (1 kHz-2 MHz) (Elins Co., Chernogolovka, Russia) on symmetric carbon/membrane/carbon cells.

\subsection{The Electrochemical Studies}

Cyclic voltammetric measurements in liquid electrolytes, i.e., in $1 \mathrm{M}$ solutions of $\mathrm{NaClO}_{4}$ in the above-mentioned mixed solvents (Section 4.1), were made to assess the electrochemical stability of the liquid phase of polymer electrolytes based on Nafion membranes. The measurements were carried out in three-electrode cells with an aluminum working electrode (foil $50 \mu \mathrm{m}$ thick, "Rusal" Co., Irkutsk, Russia). The auxiliary and the reference electrodes were made from sodium metal, rolled on a stainless 
steel mesh. To register cyclic voltammograms (CVs), a potentiostat-galvanostat R-20X8 from "Elins" (Elins Co., Chernogolovka, Russia) was used. The water content in solvents and electrolyte, determined by coulometric titration using the Karl Fischer method with a coulometric titrator 917 Ti-Touch (Metrohm, Switzerland) did not exceed $20 \mathrm{ppm}$. The potential scan rate was $10 \mathrm{mV} \cdot \mathrm{s}^{-1}$.

To evaluate the feasibility of using the polymer electrolytes under investigation in real sodium-ion batteries, coin cells with a polymer electrolyte were tested. For the sake of comparison, similar cells with liquid electrolyte ( $1 \mathrm{M}$ solutions of $\mathrm{NaClO}_{4}$ in the mixture of EC-PC) were tested as well.

For coin cells with a polymer electrolyte, positive electrodes contained $80 \mathrm{wt} \%$ $\mathrm{Na}_{3} \mathrm{~V}_{1.9} \mathrm{Fe}_{0.1}\left(\mathrm{PO}_{4}\right)_{3} / \mathrm{C}, 10 \%$ acetylene black as a conducting additive, and $10 \%$ of Nafion-Na dissolved in DMFA as a binder. For coin cells with liquid electrolyte, the positive electrodes contained $80 \% \mathrm{Na}_{3} \mathrm{~V}_{1.9} \mathrm{Fe}_{0.1}\left(\mathrm{PO}_{4}\right)_{3} / \mathrm{C}, 10 \%$ acetylene black, and $10 \%$ PVDF dissolved in $\mathrm{N}$-methylpyrrolidone. The electrodes were dried, pressed with a pressure of $1 \mathrm{ton} \mathrm{cm}^{-2}$ and further dried at a temperature of $120^{\circ} \mathrm{C}$ for $8 \mathrm{~h}$. The amount of active material on the substrate (Al foil $50 \mu \mathrm{m}$ thick, "Rusal" Co., Irkutsk, Russia) was about $5 \mathrm{mg} \cdot \mathrm{cm}^{-2}$. The coin cells were of the 2016 type. Cyclic galvanostatic tests were carried out using a computerized charge-discharge measuring and computing complex AZRVRIK $50 \mathrm{~mA}-10 \mathrm{~V}$ (NTT Buster, St. Petersburg, Russia). Coin cells were assembled in a glove box with a dry argon atmosphere (JSC Spectroscopic Systems, Moscow, Russia). The water and oxygen content in the box did not exceed 1 ppm.

\section{Conclusions}

In the present work, an estimation of the possibility of creating a sodium battery with a polymer electrolyte based on a Nafion membrane intercalated with a mixture of aprotic organic solvents and a positive electrode based on the $\mathrm{Na}_{3} \mathrm{~V}_{1.9} \mathrm{Fe}_{0.1}\left(\mathrm{PO}_{4}\right)_{3} / \mathrm{C}$ composite was made. It has been established that an important factor in the choice of the organic solvent, which impregnates the Nafion membrane in the sodium form, was the electrochemical window. It was shown that sodium batteries with a Nafion membrane electrolyte containing dimethylacetamide were characterized by capacity fading during cycling, which was due to the interaction of DMA and a negative sodium electrode. A suitable electrolyte for a sodium battery, in terms of high conductivity and electrochemical stability, was a Nafion membrane in sodium form intercalated by binary solvent ethylene carbonate-propylene carbonate. A battery with this electrolyte showed a discharge capacity of $\approx 110 \mathrm{mAh} \cdot \mathrm{g}^{-1}$ (current density of $10 \mathrm{~mA} \cdot \mathrm{g}^{-1}$ ) at room temperature and the ability to cycle without degradation during 20 cycles.

Supplementary Materials: The following are available online at http:/ /www.mdpi.com/2313-0105/4/4/61/s1. Figure S1: IR spectra of the obtained electrolytes. Figure S2: The XRD patterns of $\mathrm{Na}_{3} \mathrm{~V}_{1.9} \mathrm{Fe}_{0.1}\left(\mathrm{PO}_{4}\right)_{3} / \mathrm{C}$.

Author Contributions: Material synthesis and preparation S.N. and D.V.; investigation, D.V., T.K., and A.C.; data curation, A.C.; writing—original draft preparation, S.N. and T.K.; writing—review and editing, A.S. and A.Y.

Funding: This research was funded by Russian Science Foundation, grant number 16-13-00024.

Conflicts of Interest: The authors declare no conflict of interest.

\section{References}

1. Kundu, D.; Talaie, E.; Duffort, V.; Nazar, L.F. The emerging chemistry of sodium ion batteries for electrochemical energy storage. Angew. Chem. Int. Ed. Engl. 2015, 54, 3431-3448. [CrossRef] [PubMed]

2. Hwang, J.Y.; Myung, S.T.; Sun, Y.K. Sodium-ion batteries: Present and future. Chem. Soc. Rev. 2017, 46, 3529-3614. [CrossRef] [PubMed]

3. Skundin, A.M.; Kulova, T.L.; Yaroslavtsev, A.B. Sodium-ion batteries (a review). Russ. J. Electrochem. 2018, 54, 113-152. [CrossRef]

4. Wang, L.P.; Yu, L.; Wang, X.; Srinivasan, M.; Xu, Z.J. Recent developments in electrode materials for sodium-ion batteries. J. Mater. Chem. A 2015, 3, 9353-9378. [CrossRef] 
5. Agrawal, R.C.; Pandey, G.P. Solid polymer electrolytes: Materials designing and all-solid-state battery applications: an overview. J. Phys. D Appl. Phys. 2008, 41, 223001. [CrossRef]

6. Gao, H.; Xue, L.; Xin, S.; Park, K.; Goodenough, J.B. A plastic-crystal electrolyte interphase for all-solid-state sodium batteries. Angew. Chem. Int. Ed. Engl. 2017, 56, 5541-5545. [CrossRef] [PubMed]

7. Cao, C.; Liu, W.; Tan, L.; Liao, X.; Li, L. Sodium-ion batteries using ion exchange membranes as electrolytes and separator. Chem. Commun. 2013, 49, 11740-11742. [CrossRef] [PubMed]

8. Kulova, T.L.; Skundin, A.M. Polymer electrolytes for sodium-ion batteries. Electrochem. Energy 2018, 18, 22-48.

9. Vignarooban, K.; Kushagra, R.; Elango, A.; Badami, P.; Mellander, B.E.; Xu, X.; Tucker, T.G.; Nam, C.; Kannan, A.M. Current trends and future challenges of electrolytes for sodium-ion batteries. Int. J. Hydrogen Energy 2016, 41, 2829-2846. [CrossRef]

10. Cao, C.; Liu, W.; Tan, L.; Liao, X.; Li, L. Sodium-ion batteries using ion exchange membranes as electrolytes and separators. Chem. Commun. (Camb.) 2013, 49, 11740-11742. [CrossRef]

11. Yaroslavtsev, A.B. Ion transport in heterogeneous solid systems. Russ. J. Inorg. Chem. 2000, 45, S249-S267.

12. Armand, M. Polymer electrolytes-An overview. Solid State Ion. 1983, 9-10, 745-754. [CrossRef]

13. Yaroslavtsev, A.B. Solid electrolytes: Main prospects of research and development. 2016, 85, 1255-1276. Russ. Chem. Rev. 2016, 85, 1255-1276. [CrossRef]

14. Phair, J.W.; Badwal, S.P.S. Review of proton conductors for hydrogen separation. Ionics 2006, 12, $103-115$. [CrossRef]

15. Karpenko-Jereb, L.V.; Kelterer, A.-M.; Berezina, N.P.; Pimenov, A.V. Conductometric and computational study of cationic polymer membranes in $\mathrm{H}^{+}$and $\mathrm{Na}^{+}$-forms at various hydration levels. J. Membr. Sci. 2013, 444, 127-138. [CrossRef]

16. Safronova, E.; Golubenko, D.; Pourcelly, G.; Yaroslavtsev, A. Mechanical properties and influence of straining on ion conductivity of perfluorosulfonic acid Nafion ${ }^{\circledR}$-type membranes depending on water uptake. J. Membr. Sci. 2015, 473, 218-225. [CrossRef]

17. Cai, Z.; Liu, Y.; Liu, S.; Li, L.; Zhang, Y. High performance of lithium-ion polymer battery based on non-aqueous lithiated perfluorinated sulfonic ion-exchange membranes. Energy Environ. Sci. 2012, 5, 5690-5693. [CrossRef]

18. Liu, Y.; Cai, Z.; Tan, L.; Li, L. Ion exchange membranes as electrolyte for high performance Li-ion batteries. Energy Environ. Sci. 2012, 5, 9007-9013. [CrossRef]

19. Liu, Y.; Tan, L.; Li, L. Ion exchange membranes as electrolyte to improve high temperature capacity retention of $\mathrm{LiMn}_{2} \mathrm{O}_{4}$ cathode lithium-ion batteries. Chem. Commun. 2012, 48, 9858-9860. [CrossRef]

20. Liang, H.Y.; Qiu, X.P.; Zhang, S.C.; Zhu, W.T.; Chen, L.Q. Study of lithiated Nafion ionomer for lithium batteries. J. Appl. Electrochem. 2004, 34, 1211-1214. [CrossRef]

21. Voropaeva, D.Y.; Novikova, S.A.; Kulova, T.L.; Yaroslavtsev, A.B. Conductivity of Nafion-117 membranes intercalated by polar aprotonic solvents. Ionics 2018, 24, 1685-1692. [CrossRef]

22. Jin, Z.; Xie, K.; Hong, X.; Hu, Z.; Liu, X. Application of lithiated Nafion ionomer film as functional separator for lithium sulfur cells. J. Power Sources 2012, 218, 163-167. [CrossRef]

23. Jin, Z.; Xie, K.; Hong, X. Electrochemical performance of lithium/sulfur batteries using perfluorinated ionomer electrolyte with lithium sulfonyl dicyanomethide functional groups as functional separator. RSC Adv. 2013, 3, 8889-8898. [CrossRef]

24. Gao, J.; Sun, C.; Xu, L.; Chen, J.; Wang, C.; Guo, D.; Chen, H. Lithiated Nafion as polymer electrolyte for solid-state lithium sulfur batteries using carbon-sulfur composite cathode. J. Power Sources 2018, 382, 179-189. [CrossRef]

25. Cao, C.; Wang, H.; Liu, W.; Liao, X.; Li, L. Nafion membranes as electrolyte and separator for sodium-ion battery. Int. J. Hydrogen Energy 2014, 39, 16110-16115. [CrossRef]

26. Voropaeva, D.Y.; Novikova, S.A.; Kulova, T.L.; Yaroslavtsev, A.B. Solvation and sodium conductivity of nonaqueous polymer electrolytes based on Nafion-117 membranes and polar aprotic solvents. Solid State Ion. 2018, 324, 28-32. [CrossRef]

27. Roux, B.; Karplus, M. Ion transport in a gramicidin-like channel: Dynamics and mobility. J. Phys. Chem. 1991, 95, 4856-4868. [CrossRef]

28. Roux, B.; Karplus, M. Ion-transport in the gramicidin channel-free-energy of the solvated right-handed dimer in a model membrane. J. Am. Chem. Soc. 1993, 115, 3250-3262. [CrossRef] 
29. Klassen, J. S.; Anderson, S.G.; Blades, A.T.; Kebarle, P. Reaction enthalpies for $\mathrm{M}^{+} \mathrm{L}=\mathrm{M}^{+}+\mathrm{L}, \mathrm{Where}^{+}=\mathrm{Na}^{+}$ and $\mathrm{K}^{+}$and $\mathrm{L}=$ Acetamide, $\mathrm{N}$-Methylacetamide, N,N-Dimethylacetamide, Glycine, and Glycylglycine, from determinations of the collision-induced dissociation thresholds. J. Phys. Chem. 1996, 100, 14218-14227. [CrossRef]

30. Aboulaich, A.; Bouchet, R.; Delaizir, G.; Seznec, V.; Tortet, L.; Morcrette, M.; Rozier, P.; Tarascon, J.-M.; Viallet, V.; Dollé, M. A new approach to develop safe all-inorganic monolithic Li-ion batteries. Adv. Energy Mater. 2011, 1, 179-183. [CrossRef]

31. Delaizir, G.; Viallet, V.; Aboulaich, A.; Bouchet, R.; Tortet, L.; Seznec, V.; Morcrette, M.; Tarascon, J.M.; Rozier, P.; Dollé, M. The stone age revisited: Building a monolithic inorganic lithium-ion battery. Adv. Funct. Mater. 2012, 22, 2140-2147. [CrossRef]

32. Noguchi, Y.; Kobayashi, E.; Plashnitsa, L. S.; Okada, S.; Yamaki, J. Fabrication and performances of all solid-state symmetric sodium battery based on NASICON-related compounds. Electrochim. Acta 2013, 101, 59-65. [CrossRef]

33. Berezina, N.P.; Timofeev, S.V.; Kononenko, N.A. Effect of conditioning techniques of perfluorinated sulphocationic membranes on their hydrophylic and electrotransport properties. J. Membr. Sci. 2002, 209, 509-518. [CrossRef]

34. Chekannikov, A.; Kapaev, R.; Novikova, S.; Tabachkova, N.; Kulova, T.; Skundin, A.; Yaroslavtsev, A. $\mathrm{Na}_{3} \mathrm{~V}_{2}\left(\mathrm{PO}_{4}\right)_{3} / \mathrm{C} / \mathrm{Ag}$ nanocomposite materials for Na-ion batteries obtained by the modified Pechini method. J. Solid State Electrochem. 2017, 21, 1615-1624. [CrossRef]

35. Novikova, S.A.; Larkovich, R.V.; Chekannikov, A.A.; Kulova, T.L.; Skundin, A.M.; Yaroslavtsev, A.B. Electrical conductivity and electrochemical characteristics of $\mathrm{Na}_{3} \mathrm{~V}_{2}\left(\mathrm{PO}_{4}\right)_{3}$-based NASICON-type materials. Inorg. Mater. 2018, 54, 794-804. [CrossRef]

(C) 2018 by the authors. Licensee MDPI, Basel, Switzerland. This article is an open access article distributed under the terms and conditions of the Creative Commons Attribution (CC BY) license (http:/ / creativecommons.org/licenses/by/4.0/). 